\title{
Deskripsi Hasil Belajar Ditinjau Dari Kecenderungan Gaya Belajar Siswa pada Mata Pelajaran Kimia di MAN 2 Kota Palu
}

Describe Learning Outcomes of Students at MAN 2 Palu in Terms of the Tendency of Learning Styles in Chemistry

\author{
A. Kusumaningrum*, S. M. Sabang \\ Program Studi Pendidikan Kimia FKIP Universitas Tadulako, Palu, Indonesia \\ *e-mail: annisaakusumaningrum17@gmail.com
}

\begin{tabular}{l}
\hline Article Info \\
\hline Article History: \\
Received: 30 April 2021 \\
Accepted: 21 Mei 2021 \\
Published: 31 Mei 2021 \\
Keywords: \\
Learning Style \\
Learning Outcomes \\
\end{tabular}

\begin{abstract}
This study aimed to describe learning outcomes of students at MAN 2 Palu in terms of the tendency of learning styles in chemistry. This type of study was descriptive research. Sampling was carried out using the proportional stratified random sampling technique consisted of 93 students. Data collection technique used instruments of learning style questionnaire and learning outcomes test as well as daily test scores of Acid and Base Solutions. The results showed that students of Class XI MIA at MAN 2 Palu had various learning styles. There were 49 students (53\%) with a tendency to visual learning styles, 31 students (34\%) with an auditorial learning style, and 13 students (13\%) with a kinesthetic learning style. Students with visual learning style performed an excellent category of learning outcomes of 25,81\% compared to students with an auditorial learning style of $16 \%$ and with a kinesthetic learning style of $8,6 \%$.
\end{abstract}

\section{PENDAHULUAN}

Pendidikan adalah suatu proses yang diperlukan dalam perkembangan individu maupun masyarakat yang menekankan pada pembentukan kesadaran dan kepribadian dengan segala aspek yang dicakupnya [1]. Aspek yang perlu diperhatikan dalam pelaksanaan proses pembelajaran salah satunya adalah hasil belajar siswa, baik hasil belajar yang berkaitan dengan aspek kognitif, afektif maupun aspek psikomotorik. Ketercapaian hasil belajar dipengaruhi oleh beberapa faktor, yakni faktor internal dan faktor eksternal. Faktor internal merupakan faktor yang berasal dari dalam diri siswa, meliputi faktor fisik dan psikis seperti intelegensi, sikap, minat, bakat, gaya belajar, serta motivasi sedangkan faktor ekternal merupakan faktor yang berasal dari luar diri siswa meliputi lingkungan belajar, fasilitas belajar, dan profesionalisme guru. Komponen-komponen tersebut saling berkaitan satu sama lain, sehingga melemahnya satu komponen akan menghambat pencapaian tujuan pembelajaran.

Gaya belajar merupakan salah faktor internal yang dapat mempengaruhi hasil belajar. Gaya belajar diasumsikan mengacu pada kepribadian, kepercayaan, pilihan, serta perilaku yang digunakan oleh individu untuk membantu dalam belajar pada situasi yang telah dikondisikan. Menurut
Ghufron [2] mengungkapkan gaya belajar merupakan sebuah pendekatan yang dilakukan oleh individu untuk berkonsentrasi pada proses dan menguasai informasi yang baru dan sulit melalui persepsi yang berbeda. Menurut Mubarik [3] dalam penelitiannya menyatakan bahwa cara siswa dalam belajar dan berpikir berbeda-beda sesuai dengan karakteristiknya. Gaya belajar merupakan salah satu karakteristik siswa yang perlu diperhatikan dalam proses belajar mengajar.

Gaya belajar bersifat individual, sehingga setiap siswa memiliki cara belajar atau gaya belajar yang berbeda-beda. Gustiani [4] menjelaskan bahwa setiap siswa memiliki gaya belajarnya sendiri, yang diumpamakan seperti tanda tangan yang khas bagi dirinya sendiri. Perbedaan gaya belajar yang dipilih oleh setiap individu menunjukkan cara tercepat dan terbaik yang dilakukan dalam menyerap suatu informasi yang diperoleh. Sundayana [5] dalam tulisannya mengemukakan bahwa setiap siswa dengan gaya belajar apapun mempunyai kecenderungan yang sama baik dalam kemampuan pemecahahan masalah ataupun kemndirin belajarnya. Prashign [6] mengatakan bahwa kunci menuju keberhasilan dalam belajar dan bekerja adalah mengetahui gaya belajar atau bekerja yang unik dari setiap orang, menerima kekuatan sekaligus kelemahan diri sendiri dan sebanyak mungkin menyesuaikan preferensi pribadi dalam setiap situasi pembelajaran, pengkajian maupun pekerjaan. Dengan 
demikian, gaya belajar merupakan kunci keberhasilan siswa dalam belajar sesuai dengan pendapat Sengodan dan Zanaton [7] yang menyatakan gaya belajar merupakan metode yang digunakan oleh individu untuk memfokuskan dan menguasai informasi baru.

Gaya Belajar menurut DePorter dan Hernacki [8] terdiri tiga tipe, yaitu gaya belajar visual, gaya belajar auditorial, dan gaya belajar kinestetik. Siswa tipe visual belajar melalui apa yang mereka lihat, siswa dengan tipe auditorial belajar melalui apa yang mereka dengar, dan siswa tipe kinestetik belajar lewat gerak dan sentuhan.

Sekolah menerapkan kurikulum 2013 dengan desain menciptakan pola pembelajaran yang interaktif. Pendekatan yang disarankan dan menjadi karakter dari kurikulum 2013 yaitu pendekatan ilmiah (scientific approach) yang penerapannya memiliki tahapan yaitu menanya, mencoba, mengamati, menalar dan mengkomunikasikan yang diharapkan dapat menghasilkan peserta didik yang mampu dibidang sikap, pengetahuan, dan keterampilan [9].

Kimia adalah salah satu mata pelajaran ilmu alam yang mempelajari gejala-gejala alam, tetapi mengkhususkan diri dalam mempelajari struktur, susunan, sifat dan perubahan materi, serta energi yang menyertai perubahan materi. Menurut Arifin [10] kesulitan siswa dalam mempelajari ilmu kimia dapat bersumber pada: (1) kesulitan dalam memahami istilah, (2) kesulitan dalam memahami konsep kimia. Menurut Yukina [11] dalam tulisannya menyatakan bahwa siswa yang mengalami kesulitan istilah disebabkan karena kurangnya pemahaman siswa dalam memahami istilah kimia dan cenderung menghafal istilah-istilah tersebut mengakibatkan siswa merasa bingung dalam menyelesaikan soal. Selain kurangnya pemahaman siswa mengenai istilah siswa juga kesulitan dalam memahami konsep, penyebab siswa kurang memahami konsep yaitu siswa tidak memperhatikan saat guru menjelaskan materi yang berdampak siswa tidak memahami konsep-konsep awal telah diberikan dan kurangnya kesadaran siswa untuk terus berlatih mengerjakan soal.

Pembelajaran kimia juga diarahkan pada pendekatan saintifik di mana keterampilan proses sains dilakukan melalui percobaan untuk membuktikan sebuah kebenaran sehingga berdasarkan pengalaman secara langsung dapat membentuk konsep, prinsip, serta teori yang melandasinya. Pada umumnya, konsep-konsep dalam ilmu kimia maupun materi kimia merupakan konsep atau materi yang berupa abstrak dan kompleks sehingga siswa dituntut untuk memahami konsepkonsep tersebut dengan benar dan mendalam. Oleh sebab itu, seorang guru mata pelajaran kimia diharapkan dapat berinovasi menciptakan metode yang menarik minat belajar siswa. Hal ini sesuai dengan penelitian yang dilakukan oleh Ristiyani [12] menyatakan bahwa keberhasilan belajar siswa pada mata pelajaran kimia ditentukan oleh indikator guru dan metode belajar yang memiliki peraranan yang sangat besar.

Kesulitan siswa dalam mempelajari ilmu kimia menyebabkan banyak siswa yang mengalami kegagalan dalam mempelajari materi kimia. Kesulitan ini terkait dengan ciri-ciri ilmu kimia itu sendiri. Menurut Gabel [13] sebagian besar ilmu kimia bersifat abstrak. Malahayati [14] menyatakan penyebab lain siswa mengalami kesulitan yaitu karena siswa tidak terlibat secara aktif dalam proses pembelajaran dan siswa hanya mendengarkan saja keterangan guru secara pasif. Guru dalam hal ini lebih banyak menjelaskan dan menginformasikan semua fakta dan konsep. Konsep tertentu tidak bisa dijelaskan tanpa menggunakan analogi atau model sehingga dibutuhkan daya nalar yang tinggi dalam mempelajari ilmu kimia[15]. Menurut Bostorm [16] dalam penelitiannya mengemukakan bahwa guru yang mengajar berdasarkan perbedaan gaya belajar siswa akan lebih terorientasi pada peningkatan proses maupun hasil belajar dan lebih terbuka terhadap perubahan dibandingkan dengan guru yang tidak menggunakan gaya belajar sebagai dasar pedagogis.

Hasil observasi yang telah dilakukan di MAN 2 Kota Palu, dapat disimpulkan dalam proses pembelajaran terdapat siswa yang mudah memahami dan ada pula yang mengalami kesulitan dalam menyerap pelajaran kimia. Hal ini menandakan bahwa siswa memiliki karakteristik yang berbeda-beda dalam belajar dikelas, diantaranya ada siswa meminta guru untuk menuliskan contoh soal dan jawabannya di papan tulis, siswa akan lebih mudah memahami materi yang dipaparkan dibandingkan materi yang disajikan oleh guru melalui slide presentasi atau yang dituliskan di papan tulis dan terdapat siswa dalam pembelajaran cenderung aktif melakukan gerakan-gerakan, dan lebih aktif dalam pembelajaran yang melibatkan dirinya secara langsung. Siswa memiliki cara yang berbeda-beda dalam menerima suatu informasi yang disampaikan oleh guru sehingga menyebabkan hasil belajar siswa berbeda-beda. Setiap siswa mempunyai gaya belajar yang alami dan nyaman, ketika dipaksa untuk belajar dengan cara lain maka akan timbul rasa tidak nyaman sehingga pembelajaran akan semakin sulit.

Keberhasilan proses pembelajaran tidak bisa lepas dari gaya belajar siswa dan gaya mengajar guru. Masing-masing individu belajar dengan cara yang berbeda. Seorang individu dapat merasa kesulitan apabila dipaksa mempelajari sesuatu dengan metode yang bukan gaya belajarnya. Satu gaya belajar tertentu belum tentu berhasil pada semua individu. Siswa sebaiknya memahami gaya belajar yang dimilikinya, sehingga akan lebih mudah bagi mereka dalam mempelajari sesuatu dan meningkatkan motivasi untuk menampilkan kemampuan yang terbaik. Guru sebagai pendidik kiranya dapat memahami gaya belajar siswa sehingga akan semakin mungkin menyajikan gaya mengajar yang sesuai dengan kebutuhan siswa dan dapat meningkatkan hasil belajar.

Tulisan ini dimaksudkan untuk mendeskripsikan tentang hasil belajar ditinjau dari kecenderungan gaya belajar siswa pada mata pelajaran kimia di MAN 2 Kota Palu.

\section{METODE}

Jenis penelitian ini adalah penelitian deskriptif. Penelitian ini mendeskripsikan hasil belajar siswa yang diperoleh ditinjau dari kecenderungan gaya belajar. Menurut pendapat Nawawi [17] bahwa metode deskriptif merupakan prosedur pemecahan masalah yang sedang diselidiki berdasarkan fakta-fakta yang tampak sebagaimana adanya dengan menggambarkan atau melukiskan keadaan subjek atau objek penelitian pada saat sekarang. Penelitian ini dilaksanakan di MAN 2 Kota Palu, jalan Moh. Husni Thamrin No. 41 Palu Timur, Sulawesi Tengah. 
Variabel penelitian yang digunakan oleh peneliti adalah dua macam variabel adalah sebagai berikut:

1. Variabel Bebas (X) adalah gaya belajar siswa

2. Variabel Terikat (Y) adalah hasil belajar siswa kelas XI MIA pada mata pelajaran kimia.

Populasi penelitian yang digunakan adalah siswa kelas XI MIA MAN 2 Kota Palu yang terdaftar pada tahun ajaran 2018/2019. Dalam penelitian ini digunakan sampel yang ditentukan dengan cara menggunakan teknik pengambilan sampel proporsionate stratified random sampling. Teknik tersebut menurut Riduwan [18] ialah pengambilan sampel dari anggota populasi secara acak dan berstrata secara proporsional. Berikut uraian pengambilan sampel pada penelitian ini: Penentuan jumlah sampel menggunakan rumus Yamane [18] sebagai berikut.

$$
\mathbf{n}=\frac{\mathrm{N}}{\mathbf{N} \cdot \mathbf{d}^{2}+1}
$$

Keterangan:

$\mathrm{n} \quad=$ Jumlah sampel

$\mathrm{N}=$ Jumlah Populasi

$\mathrm{d} \quad=$ Presisi yang ditetapkan $(5 \%$ atau 0,05$)$

Jenis data dalam penelitian berupa data hasil analisis angket dan data tes hasil belajar kimia sedangkan sumber data dalam penelitian ini diperoleh langsung dari siswa MAN 2 Kota Palu.

Data yang diperoleh dalam penelitian ini diperoleh dengan cara memberikan angket dan tes hasil belajar. Tes hasil belajar ialah seperangkat rangsangan yang diberikan kepada seseorang yang bermaksud untuk mendapatkan jawaban yang dapat digunakan sebagai dasar untuk penetapan skor angka. Tes yang digunakan pada penelitian ini adalah tes gaya belajar yang terdiri atas 9 nomor. Tes dalam penelitian ini digunakan untuk melihat hasil belajar siswa.

Instrumen penelitian merupakan suatu alat yang digunakan untuk mengukur fenomena alam maupun sosial yang diamati. Secara spesifik semua fenomena ini disebut variabel penelitian [19]. Instrumen yang digunakan dalam penelitian ini adalah kuesioner (angket) dan tes hasil belajar yang sebelumnya telah divalidasi.Valid berarti instrumen telah diuji cobakan dapat digunakan untuk mengukur apa yang seharusnya diukur. Sugiyono [19] mengemukakan valid berarti instrumen tersebut dapat digunakan untuk mengukur apa yang seharusnya diukur. Definisi validitas dikemukakan oleh Yusuf [20] bahwa validitas suatu instrumen yaitu seberapa jauh instrumen itu benarbenar mengukur apa (objek) yang hendak diukur. Dalam penelitian ini akan menguji validitas angket dan tes hasil belajar menggunakan rumus Korelasi Product Moment.

Instrumen yang valid belum tentu reliabel. Menurut Yusuf [20] reliabilitas merupakan konsistensi atau kestabilan skor suatu instrument penelitian terhadap individu yang sama dan diberikan dalam waktu yang berbeda. Sama halnya dengan uji validitas pada penelitian ini terdapat dua jenis instrumen pengumpulan data yang berbeda yaitu angket dan tes hasil belajar. Perhitungan untuk mencari harga reliabilitas angket dan tes hasil belajar dijabarkan pada pendapat Arikunto [21] yang menyatakan bahwa untuk menghitung reliabilitas dapat digunakan rumus korelasi alpha cronbach.
Teknik analisis data yang digunakan pada penelitian ini adalah dengan metode analisis statistik deskriptif. Data yang dikumpulkan dianalisis dengan teknik analisis deskriptif kuantitatif bertujuan untuk memberikan gambaran realistis dan sistematis. Sugiyono [19] mengemukakan statistik deskriptif adalah statistik yang digunakan untuk menganalisis data yang telah terkumpul sebgaimana adanya tanpa bermaksud membuat kesimpulan yang berlaku untuk umum atau generalisasi.

\section{HASIL DAN PEMBAHASAN}

Data yang diperoleh pada penelitian ini berupa tipe gaya belajar siswa dan hasil belajar. Hasil belajar diperoleh dari nilai tes berdasarkan tipe gaya belajar dan nilai ulangan harian pada materi larutan asam dan basa. Nilai ulangan harian yang diperoleh digunakan sebagai pembanding.

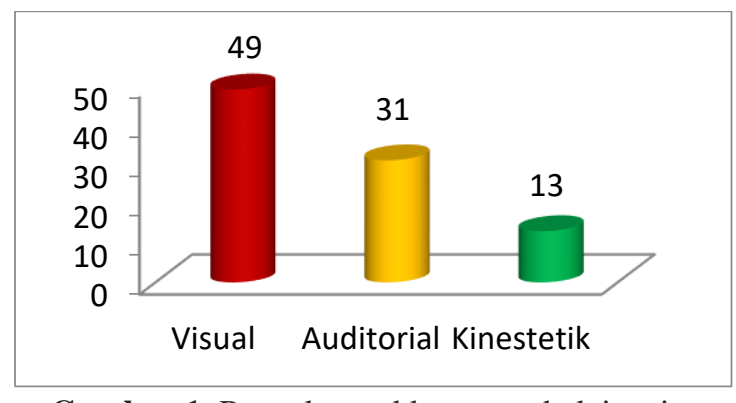

Gambar 1. Pengelompokkan gaya belajar siswa

Hasil analisis data tersebut memberikan gambaran bahwa dari 93 siswa kelas XI MIA di MAN 2 Kota Palu yang mengisi angket gaya belajar menunjukkan ada 49 siswa (53\%) yang memiliki kecenderungan gaya belajar visual, ada 31 siswa (34\%) yang memiliki kecendrungan gaya belajar auditorial, dan ada 13 siswa (13\%) yang memiliki kecendrungan gaya belajar kinestetik. Data tersebut menunjukkan bahwa gaya belajar yang dominan dimiliki oleh siswa kelas XI MIA adalah tipe gaya belajar visual. Siswa cenderung belajar dengan cara melihat langsung materi yang diajarkan dan juga siswa akan lebih memahami materi apabila materi tersebut dituliskan di papan tulis atau dengan menggunakan media seperti alat peraga dan sebagainya.

Data hasil belajar kimia yang diperoleh dilakukan pengkategorian untuk menunjukkan kategori hasil belajar berada pada kategori yang mana, maka terdapat 5 kategori yaitu sangat baik, baik, cukup, kurang, dan sangat kurang seperti yang terdapat pada Tabel 1 .

Tabel 1. Kategori hasil belajar siswa

\begin{tabular}{cc}
\hline Kategori & Nilai \\
\hline Sangat Baik & $80-100$ \\
Baik & $66-79$ \\
Cukup & $56-65$ \\
Kurang & $40-55$ \\
Sangat Kurang & $30-39$ \\
\hline
\end{tabular}


Data hasil belajar yang diperoleh dikelompokkan berdasarkan tipe gaya belajar siswa untuk mengetahui hasil belajar siswa ditinjau dari kecenderungan gaya belajar yang dimilikinya. Demikian data hasil belajar sesuai dengan tipe gaya belajarnya.

Tabel 2. Distribusi kategori hasil belajar siswa terhadap gaya belajar visual

\begin{tabular}{lccc}
\hline \multicolumn{1}{c}{ Kategori } & $\begin{array}{c}\text { Rentang } \\
\text { Nilai }\end{array}$ & Frekuensi & $\begin{array}{c}\text { Persen } \\
(\boldsymbol{\%})\end{array}$ \\
\hline Sangat Baik & $80-100$ & 15 & 31 \\
Baik & $66-79$ & 24 & 49 \\
Cukup & $56-65$ & 10 & 20 \\
Kurang & $40-55$ & 0 & 0 \\
Sangat & & & \\
Kurang & $30-39$ & 0 & 0 \\
\hline
\end{tabular}

Hasil belajar yang diperoleh siswa dengan kecenderungan gaya belajar visual berada pada kategori sangat baik dengan persentase $31 \%$ (15 siswa), kategori baik dengan persentase 49\% (24 siswa), dan kategori cukup 20\% (10 siswa) seperti yang terlihat pada Tabel 2 .

Tabel 3. Distribusi kategori hasil belajar siswa terhadap gaya belajar auditorial

\begin{tabular}{lccc}
\hline Kategori & $\begin{array}{c}\text { Rentang } \\
\text { Nilai }\end{array}$ & Frekuensi & $\begin{array}{c}\text { Persen } \\
(\mathbf{\%})\end{array}$ \\
\hline Sangat & $80-100$ & 8 & 26 \\
Baik & $66-79$ & 15 & 48 \\
Baik & $56-65$ & 6 & 19 \\
Cukup & 2 & 7 \\
Kurang & $40-55$ & 0 & 0 \\
Sangat & $30-39$ & 0 \\
Kurang & & & \\
\hline
\end{tabular}

Tabel 3 memuat hasil belajar yang diperoleh siswa dengan kecenderungan gaya belajar auditorial berada pada kategori sangat baik dan baik dengan persentase 26\% (8 siswa), kategori baik dengan 48\% (15 siswa), kategori cukup 19\% (6 siswa) dan kurang 7\% (2 siswa). Menurut Elytasari [22] dalam tulisannya mayoritas siswa belajar dengan menggunakan gaya auditori dengan nilai rata-rata siswa sebesar 85,69 dan termasuk dalam kategori baik

Tabel 4. Distribusi kategori hasil belajar siswa terhadap gaya belajar kinestetik

\begin{tabular}{lccc}
\hline Kategori & $\begin{array}{l}\text { Rentang } \\
\text { Nilai }\end{array}$ & Frekuensi & $\begin{array}{l}\text { Persen } \\
(\%)\end{array}$ \\
\hline Sangat & $80-100$ & 2 & 15 \\
Baik & $66-79$ & 8 & 62 \\
Baik & $56-65$ & 3 & 23 \\
Cukup & $40-55$ & 0 & 0 \\
Kurang & $30-39$ & 0 & 0 \\
Sangat & & & 0 \\
Kurang & &
\end{tabular}

Hasil belajar yang diperoleh siswa dengan kecenderungan gaya belajar auditorial berada pada kategori sangat baik dengan persentase $15 \%$ ( 2 siswa), kategori baik $62 \%$ (8 siswa) dan kategori cukup 23\% (3 siswa) seperti yang terlihat pada Tabel 4.

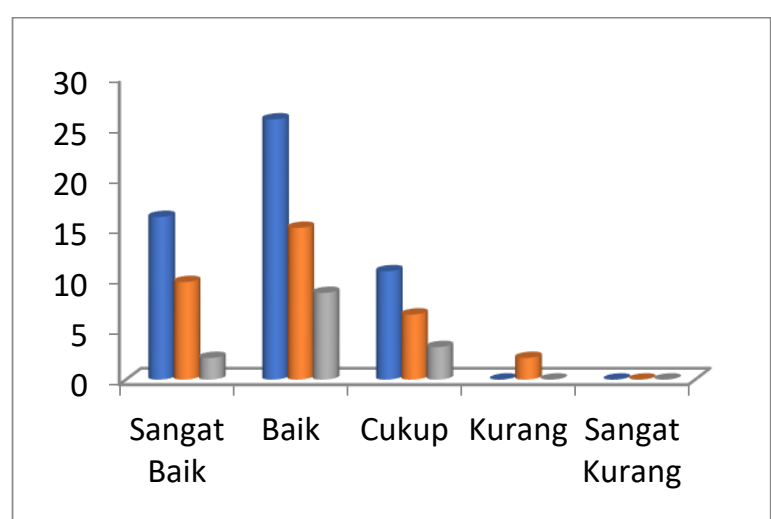

Gambar 2. Perbandingan hasil belajar siswa berdasarkan gaya belajar $\square$ visual, $\square$ uditorial, $\square$ kinestetik)

Gambar 2 mendekripsikan data mengenai hasil belajar siswa kelas XI MIA pada mata pelajaran kimia di MAN 2 Kota Palu dimana menunjukkan bahwa siswa yang memiliki hasil belajar dominan dengan kategori baik ditinjau dari hasil tes gaya belajar siswa dengan kecenderungan gaya belajar visual sebesar $25,81 \%$, jika dibandingkan dengan siswa yang memiliki kecenderungan gaya belajar auditorial dan kinestetik sebesar $16 \%$ dan $8,6 \%$. Hal ini sesuai dengan penelitian yang dilakukan Bire [23] yang menyatakan bahwa gaya belajar visual memiliki pengaruh yang cukup kuat terhadap prestasi belajar siswa. Menurut Hasanah [24] dalam penelitiannya gaya belajar yang berpengaruh dominan terhadap hasil belajar siswa yaitu gaya belajar visual sebesar $35,00 \%$, sedangkan sisanya 19,2\% dipengaruhi oleh faktor lain. Hasil yang diperoleh diperkuat oleh Mulyono dkk. [25] dalam tulisannya menyatakan gaya belajar visual berpengaruh positif terhadap prestasi belajar yang diperoleh siswa/mahasiswa. Pemberian informasi materi pelajaran melalui gambar atau diagram merupakan stimulus dalam gaya belajar visual sebagai respon dari penerimaan informasi. Wassahua [26] dalam penelitiannya menjelasakan bahwa siswa yang cenderung memiliki gaya belajar visual hasil belajarnya lebih baik dibandingkan siswa yang memiliki gaya belajar auditori dan kinestetik.

Kriteria ketuntasan minimal pada mata pelajaran kimia yaitu 70. Berdasarkan KKM dapat diketahui siswa yang tuntas sebanyak 66 siswa (71\%) dan 27 siswa (29\%) tidak tuntas. Sedangkan jika dibandingkan dengan nilai ulangan harian yang diperoleh siswa yang tuntas sebanyak 50 siswa (54\%) dan yang tidak tuntas sebanyak 43 siswa (46\%). Hal ini menandakan bahwa pemberian test hasil belajar sebaiknya mempertimbangkan tipe gaya belajar yang dimiliki oleh siswa sehingga hasil belajarnya akan meningkat.

Gaya belajar adalah suatu kebiasaan atau suatu cara yang dilakukan oleh siswa untuk menangkap stimulus, menyerap, dan mengatur serta mengolah informasi yang diperoleh pada proses belajar. Setiap siswa memiliki gaya belajar yang berbeda dan memilki kemampuan yang berbeda saat mengingat dan menginformasikan serta dapat memecahkan masalah soal dengan menggunakan kemampuan yang baik yang dapat mempengaruhi hasil belajar. Menurut Khoeron 
[25] gaya belajar memiliki pengaruh tinggi terhadap pencapaian prestasi belajar peserta didik semakin sesuai gaya belajar dengan kepribadian peserta didik maka akan semakin tinggi prestasi akademik peserta didik tersebut.

Gaya belajar pada siswa akan menimbulkan usaha yang gigih dan pantang menyerah dalam belajar. Siswa yang memahami gaya belajarnya akan mampu memanfaatkan potensi yang dimiliki untuk dapat terus berkembang dan mengasah kemampuannya, sebaliknya siswa yang tidak memahami gaya belajar yang dimilikinya akan cenderung pasif dan sulit memahami materi pelajaran akibatnya hasil belajar yang diperoleh rendah. Menurut Widayanti [26] dalam penelitiannya mengemukakan bahwa dengan mengembangkan gaya belajar yang paling tidak disukai siswa dapat meningkatkan kemampuannya untuk belajar dan berhubungan dengan temannya.

Faktor- faktor lain yang mempengaruhi hasil belajar siswa meliputi lingkungan belajar, teman sebaya, serta motivasi dari orang tua dan guru. Lingkungan belajar memiliki peran yang penting karena dengan memberikan lingkungan belajar yang nyaman siswa dapat belajar dengan senang dan nyaman.Selain itu perlunya pengawasan dan motivasi yang dilakukan oleh orang tua dan guru. Orang tua dan guru senantiasa memberikan motivasi dan semangat kepada siswa untuk bersungguh-sungguh dalam belajar dan membantu kesulitan siswa dalam memahami materi pelajaran.

\section{KESIMPULAN}

Berdasarkan hasil analisis data penelitian, dapat disimpulkan bahwa Siswa di MAN 2 Kota Palu memiliki hasil belajar dengan kategori sangat baik dengan persentase $16,13 \%$ untuk siswa dengan tipe gaya belajar visual 9,68\% auditorial, 2,15\% kinestetik. Sedangkan untuk kategori hasil belajar baik dengan persentase visual $25,81 \%$, auditorial $16 \%$ dan kinestetik $8,6 \%$. Kategori cukup dengan persentase $10,75 \%$ gaya belajar visual, $6,45 \%$ auditorial dan 3,23\% untuk gaya belajar kenestetik. Sedangkan pada kategori kurang hanya terdapat pada tipe gaya belajar auditorial dengan persentase sebesar $2,15 \%$.

\section{UCAPAN TERIMA KASIH}

Penulis mengucapkan terima kasih kepada kepala MAN 2 Kota Palu, guru mata pelajaran kimia dan Siswa-siswi kelas XI MIA tahun ajaran 2018/2019, serta semua pihak yang banyak membantu penulis dalam menyelesaikan penelitian ini.

\section{REFFERENSI}

[1] Nurkholis, "Pendidikan dalam Memajukan Teknologi". Jurnal Kependidikan, 2013, 1(1), 24-44.

[2] N. Ghufron, \& R. Risnawati, "Gaya Belajar Kajian Teoretik”. Yogyakarta: Pustaka Belajar, 2012.

[3] Mubarik. "Profil pemecahan masalah siswa auditorial kelas X SLTA pada materi sistem persamaan linear dua variabel". Jurnal Elektronik Pendidikan Matematika Tadulako, 1(1), 2013, pp: 1-9.
[4] Gustiani, L. "Hubungan antara gaya belajar (visual, auditory dan kinestetik) dengan kecerdasan intraporsional siswa kelas tinggi di SDN 03 Kota Bengkulu”. Skripsi. Bengkulu: Universitas Bengkulu, 2014.

[5] Sundayana, R. "Kaitan antara gaya belajar, kemandirian belajar, dan kemampuan pemecahan masalah siswa SMP dalam pelajaran matematika," Jurnal Pendidikan Matematika STKIP Garut, 5(2), 2016, pp. 75-84.

[6] Prashign, B. "The power of learning styles: Memicu anak melejitkan prestasi dengan mengenali gaya belajarnya”. Bandung: Kaifa, 2007.

[7] Sengodan, V., \& Zanaton, H. I. "Students learning style and intrinsic motivation in learning mathematics," Assian Social Science, 8(16), 2012, pp. 17-23.

[8] DePorter, B \& Hernacky, M. “Quantum learning”. Jakarta: Kaifa, 2005.

[9] Putri, C. A. I., Putra, K. N. D., \& Zulaikha, S. "Pengaruh metode pembelajaran SQ3R terhadap hasil belajar bahasa Indonesia kelas V," Jurnal Mimbar PGSD Universitas Pendidikan Ganesha Jurusan PGSD, 2(1), 2014, pp.1-11.

[10] Arifin, M. "Strategi belajar mengajar kimia". Bandung: JICA IMSTED UPI Bandung, 2000.

[11] Yukina, Tuti, K., \& Raudhatul, F. “Analisis kesulitan belajar siswa pada mata pelajaran kimia kelas X di SMA Negeri 1 Sungai Ambawang," Ar-Razi Jurnal Ilmiah, 5(2), 2017, pp. 287-297.

[12] Ristiyani, E., \& Evi, S. B. "Analisis kesulitan belajar kimia siswa di SMAN X Kota Tanggerang Selatan," Jurnal Penelitian dan pembelajaran IPA, 2(1), 2016, pp. 18-29.

[13] Gabel, D. "Improving teaching and learning through chemistry education research: A look to the future," Journal of Chemical Education, 76(4), 1999, pp. 548554.

[14] Malahayati, S. "Penerapan model pembelajaran inquiri berbasis praktikum untuk meningkatkan penguasaan konsep dan keterampilan berfikir kritis siswa kelas X SMAN 2 Meureude pada materi rangkaian listrik," Jurnal Pendidikan Sains Indonesia, 4(2), 2016, pp. 25-31.

[15] Yunitasari, W., Susilowati, E., \& Nurhayati, D. "Pembelajaran direct instruction disertai hierarki konsep untuk mereduksi miskonsepsi siswa pada materi larutan penyangga kelas XI semester genap SMA Negeri 2 Sragen tahun ajaran 2012/2013," Jurnal Pendidikan Kimia (JPK), 2(3), 2013, pp. 182-190. 
[16] Bostrom, L. "Effect of learning style responsive versus traditional approaches on grammar," Institute of Learning Style Journal, 1(3), 2011, pp. 17-38.

[17] Nawawi, H. "Metode Penelitian Bidang Sosial". Yogyakarta: Gajah Mada University Press, 2012.

[18] Riduwan. "Dasar-Dasar Statistic”. Bandung: Alfabeta, 2010.

[19] Sugiyono. “Metode Penelitian Pendidikan”. Bandung: Alfabeta, 2016.

[20] Yusuf, A. M. "Metodologi penelitian kuantitatif, kualitatif \& penelitian gabungan”. Jakarta: Prenadamedia Group, 2014.

[21] Arikunto, S. "Dasar-dasar Evaluasi Pendidikan”. Jakarta: Bumi Aksara, 2012.

[22] Elytasari, M., Iceng, H., \& A. Rachman, I. "Gaya belajar dan prestasi belajar kimia siswa SMA,” Jurnal Penelitian Pendidikan Kimia, 2(1), 2015, pp. 44-50.

[23] Bire, A. L., Uda, G., \& Josua, B. "Pengaruh gaya belajar visual, auditorial, dan kinestetik terhadap prestasi belajar siswa," Jurnal kependidikan, 44(2), 2014, pp. 168-174.

[24] Hasanah, I., Sri, K., \& Sutrisno, D. "Pengaruh gaya belajar terhadap hasil belajar siswa kelas XI jurusan akuntansi pada kompetensi dasar jurnal khusus di SMK Negeri 1 Jember semester genap tahun ajaran 2017/2018," Jurnal Pendidikan Ekonomi, 12(2), 2018, pp. 277-282.

[25] Khoeron, I. R., Nana, S., \& Tatang, P. "Pengaruh gaya belajar terhadap prestasi belajar peserta didik pada mata pelajaran produktif," Journal of Mechanical Engineering Education, 1(2), 2014, pp. 291-297.

[26] Wassahua, S. “Analisis gaya belajar siswa terhadap hasil belajar matematika pada materi himpunan siswa kelas VII SMP Negeri Karang Jaya Kecamatan Namlea Kabupaten Buru, ” Jurnal Matematika dan Pembelajarannya, 2(1), 2016, pp. 84-104.

[27] Mulyono, W. A., Purwandari, H., \& Permana, R. H. "Pengaruh pelatihan gaya belajar terhadap peningkatan indeks prestasi mahasiswa," Jurnal Keperawatan Soedirman (The Soedirman Journal of Nursing), 2(3), 2007, pp. 134-140.

[28] Widayanti, F. D. "Pentingnya mengetahui gaya belajar siswa dalam kegiatan pembelajaran di kelas," ERUDIO, 2(1), 2013, pp. 7-21. 